\title{
Vegetational History of the Area around Kashira Island in the Inland Sea, Okayama Prefecture, Western Japan
}

\author{
Toshiyuki FUJIKI*, Yoshimune MORITA** and Norio MIYOSHI***
}

\begin{abstract}
Kashira Island is situated in the Inland Sea, near Hinase town, Okayama Prefecture. The 44-m core consisted of clay, sandy clay, gravel with sand, humus and tephra (Aira : 2,540-2,390 cm depth, Akahoya : $1,900-1,890 \mathrm{~cm}$ depth). The humus portion $(2,368-2,360$ $\mathrm{cm}$ depth) was dated to $21,100 \pm 400 \mathrm{yr}$ B.P. by the ${ }^{14} \mathrm{C}$-dating method.

Pollen analysis revealed the core to consist of nine pollen and two barren zones. Layers containing Lagerstroemia pollen, the important index taxa for the warm period, were regarded as sediments of the warm period. This core may contain the sediments of four warm (KS-9, 8, 6, 4-1) and three cold periods (KS-7, 5 and $\mathrm{BZ}-2,1$ ). KS-4-1 represent the post glacial period.
\end{abstract}

Key words pollen analysis, cold and warm period cycle, Lagerstroemia

\section{Introduction}

Many pollen analyses have been carried out in the Chugoku Mountains by palynologists such as Yamazaki (1943), Nakamura (1959) and Miyoshi and Yano (1986), and the vegetational history and climate changes have been well clarified. However, moors and marshes are very rare near the coast of the Inland Sea, because of warm weather and little annual rainfall. Furthermore, most swampy places have been changed to paddy fields and lands for housing. There are a few palynological works, such as those of Furutani (1989) and Miyoshi (1994a).

This background was considered in relation to a geological survey for harbor construction by Fukken Research and Planning Corporation, Okayama. The purpose of this study was to clarify the vegetational history around Kashira Island.

\section{Site description}

Kashira Island is situated about $4 \mathrm{~km}$ from Hinase town, Okayama Prefecture (coordinates $\left.34^{\circ} 41^{\prime} \mathrm{N}, 134^{\circ} 17^{\prime} \mathrm{E}\right)$ in the Inland Sea, western Japan (Fig. 1). Some meteorological data for the island are as follows: annual temperature, $15.1^{\circ} \mathrm{C}$; lowest monthly mean temperature, $4.5^{\circ} \mathrm{C}$ (Jan) ; highest monthly mean temperature, $26.8^{\circ} \mathrm{C}$ (Aug); total annual precipitation, $1,231.9 \mathrm{~mm}$.

${ }^{*}$ International Research Center for Japanese Studies, Oeyama-cho 3-2, Goryo, Nishikyo-ku, Kyoto 610-1192, Japan

** Botanical Garden, Institute of Natural Science, Okayama University of Science, Ridai-cho 1-1, Okayama 700-0005, Japan

*** Biosphere-Geosphere System Science, Faculty of Informatics, Okayama University of Science, Ridaicho 1-1, Okayama 700-0005, Japan 


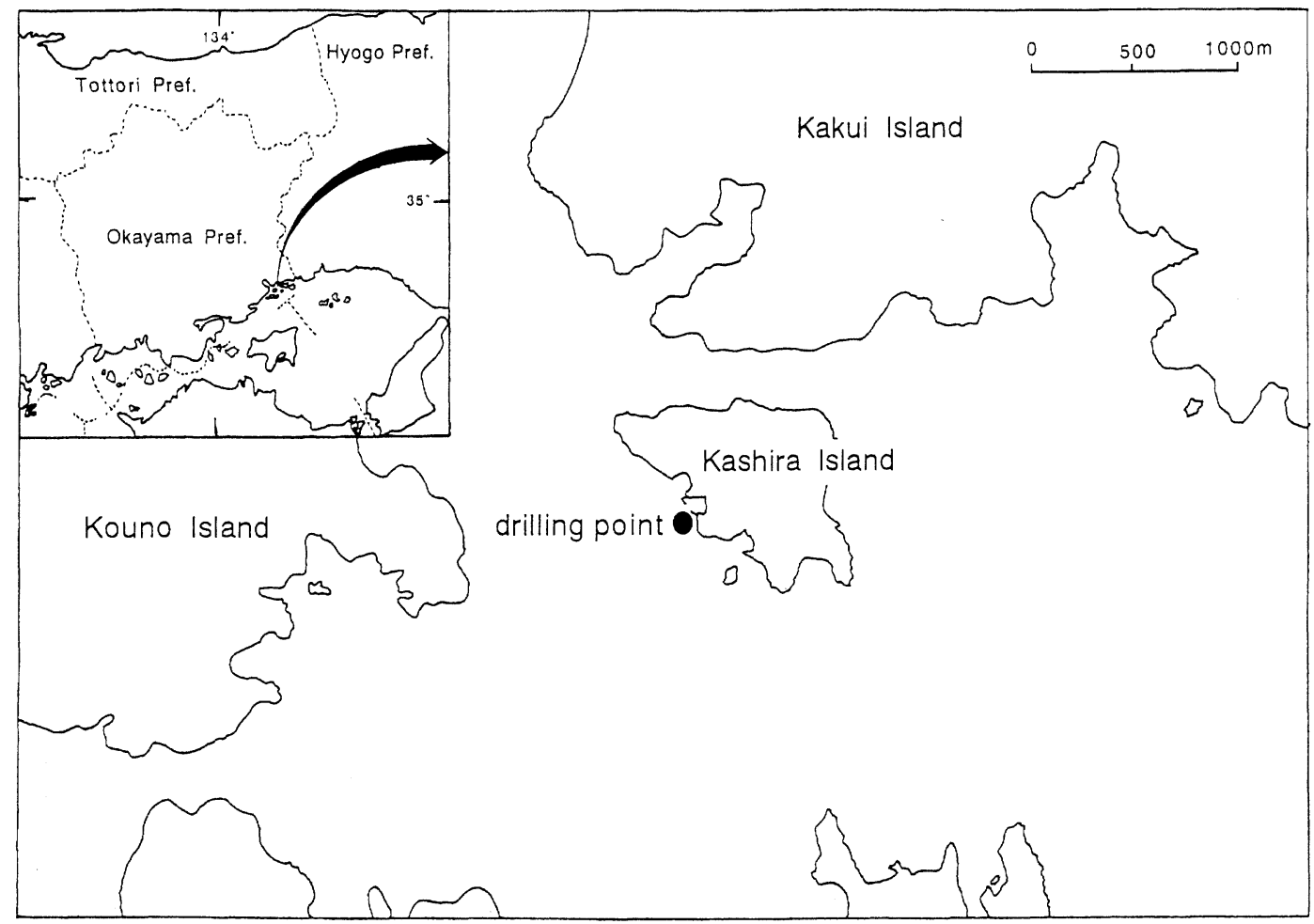

Fig. 1 Map giving the position of the drilling point.

The climate is warm and little annual rainfall and it is known as having the climatic type termed Seto-uchi (the Inland Sea) (Hada, 1996). On Kashira Island, secondary forest of Pinus densiflora is dominant, although a number of $P$. densiflora have died because of weevil infection. In the southern part of the island there are some small forests dominated by Pinus thunbergii, $P$. densiflora, Cinnamomum comphora and Mallotus japonicus. In the northern part of the island there are tangerine orchards and some forests dominated by Celtis sinensis, Cinnamomum japonicum and Eurya japonica (Hada, 1975). Around the drilling site the present dominant species is $P$. densiflora.

\section{Material and Methods}

The 44-m core sample was collected in October 1994. The drilling site is approximately $300 \mathrm{~m}$ from the seashore and at a $4.27 \mathrm{~m}$ water depth. From the bottom to the surface there are six kinds of sediments : clay $(4,375-4,090 \mathrm{~cm}, 3,300-$ $2,985 \mathrm{~cm}, 2,300-0 \mathrm{~cm})$, humus $(2,390-2,300 \mathrm{~cm})$, sandy clay $(3,700-3,570 \mathrm{~cm}, 2,600-2,540 \mathrm{~cm})$, sand $(2,670-2,600 \mathrm{~cm})$, gravel with sand $(4,090-3,700 \mathrm{~cm}$, 2,985-2,670 cm), gravel with sandy clay $\left(3,570^{-}\right.$ $3,300 \mathrm{~cm}$ ) and tephra (Aira : ca. 25,000 yr B.P. 2,540-2,390 cm, and Akahoya : ca. 6,300 yr B.P. $1,900-1,890 \mathrm{~cm})$. One sample for ${ }^{14} \mathrm{C}$-dating was taken from the humus at the depth of 2,368-2,360 $\mathrm{cm}$. 
The core was cut at $5^{-} \mathrm{cm}$ intervals and each piece was put in a vinyl bag, and kept at $-20^{\circ} \mathrm{C}$ until needed for laboratory studies. The samples for pollen analysis were obtained at intervals of $30-40 \mathrm{~cm}$. The samples used for the pollen analysis were $3 \mathrm{~cm}$ in thickness. The sample for ${ }^{14} \mathrm{C}^{-}$ dating was dried in a hot-air drier and sent to the Kyushu Environment Management Association at Fukuoka. Fossil pollen and spores were extracted by boiling in $10 \% \mathrm{KOH}$ solution and by applying mineral separation with $\mathrm{ZnCl}_{2}$ solution (s.g. 1.78). The samples were subsequently treated with $40 \% \mathrm{HF}$ and then with Erdtman's acetolysis method. In making the slides the treated materials were mounted in glycerine jelly. Samples for scanning electron microscope were fixed with $2 \%$ osmium tetroxide after acetolysis, then dehydrated with $99.5 \%$ ethanol and substituted with xylene. The samples were put on the stand of an ion spattering apparatus and spattered with goldpalladium for about five minutes and then observed with the high-resolution scanning electron microscope (HR-SEM : JEOL-890).

In the pollen diagram, percentages for each taxon were calculated for the sum-total of the AP (arboreal pollen). At least 500 pollen grains were counted per level. However Alnus pollen was excluded from the summed arboreal pollen, because the high frequencies and fluctuations of
Alnus pollen, considered to be derived mainly from Alnus thickets which are abundant on wet land, affect the frequencies of other upland arboreal taxa. The pollen of Buxus, Ilex, Elaeagnus, Ligustrum, Clethra, Ericaceae and Weigela, which are regarded as bushes, are excluded from the summed arboreal pollen.

\section{Results}

\section{Dating}

${ }^{14} \mathrm{C}$-dating yielded the age of $21,100 \pm 400 \mathrm{yr}$ B.P. (at the depth of 2,368-2,360 cm, KEEA-52).

Two tephra layers corresponded to widespread late Quaternary tephra deposited at 6,300 yr B.P. (1,900-1,890 cm, Akahoya) and 25,000 yr B.P. (2,540-2,390 cm, Aira) based on an estimate using lithologic characters (Table 1).

\section{Analytical results}

Seventy-eight varieties of fossil pollen and spores were detected. These were divided into AP (arboreal pollen), NAP (non-arboreal pollen) and FS (fern spores), as described below. The genus order follows the classification of Ohwi and Kitagawa (1992).

AP : Podocarpus, Abies, Tsuga, Picea, Pinus (Diploxylon), Pinus (Haploxylon), Sciadopitys, Cryptomeria, Cupressaceae, Ephedra, Salix, Myrica, Platycarya, Pterocarya, and/or Juglans, Carya, Carpinus, Corylus, Betula, Alnus, Fagus,

Table 1 The characteristics of volcanic glass from Kashira Island

\begin{tabular}{l|c|l|l}
\hline \hline \multicolumn{1}{c|}{ Tephra } & Refractive index & Morphology of volcanic glass & \multicolumn{1}{c}{ Color of volcanic glass } \\
\hline K-Ah (Machida \& Arai, 1992) & $1.508-1.516$ & bubble wall type \& pumice type & transparency \& light-brown \\
Kashira Is. (1,900-1,890 cm) & $1.505-1.509$ & bubble wall type \& pumice type & transparency \& light-brown \\
AT (Machida \& Arai, 1992) & $1.498-1.501$ & bubble wall type \& pumice type & transparency \\
Kashira Is. (2,540-2,390 cm) & $1.499-1.503$ & bubble wall type \& pumice type & transparency \\
\hline
\end{tabular}




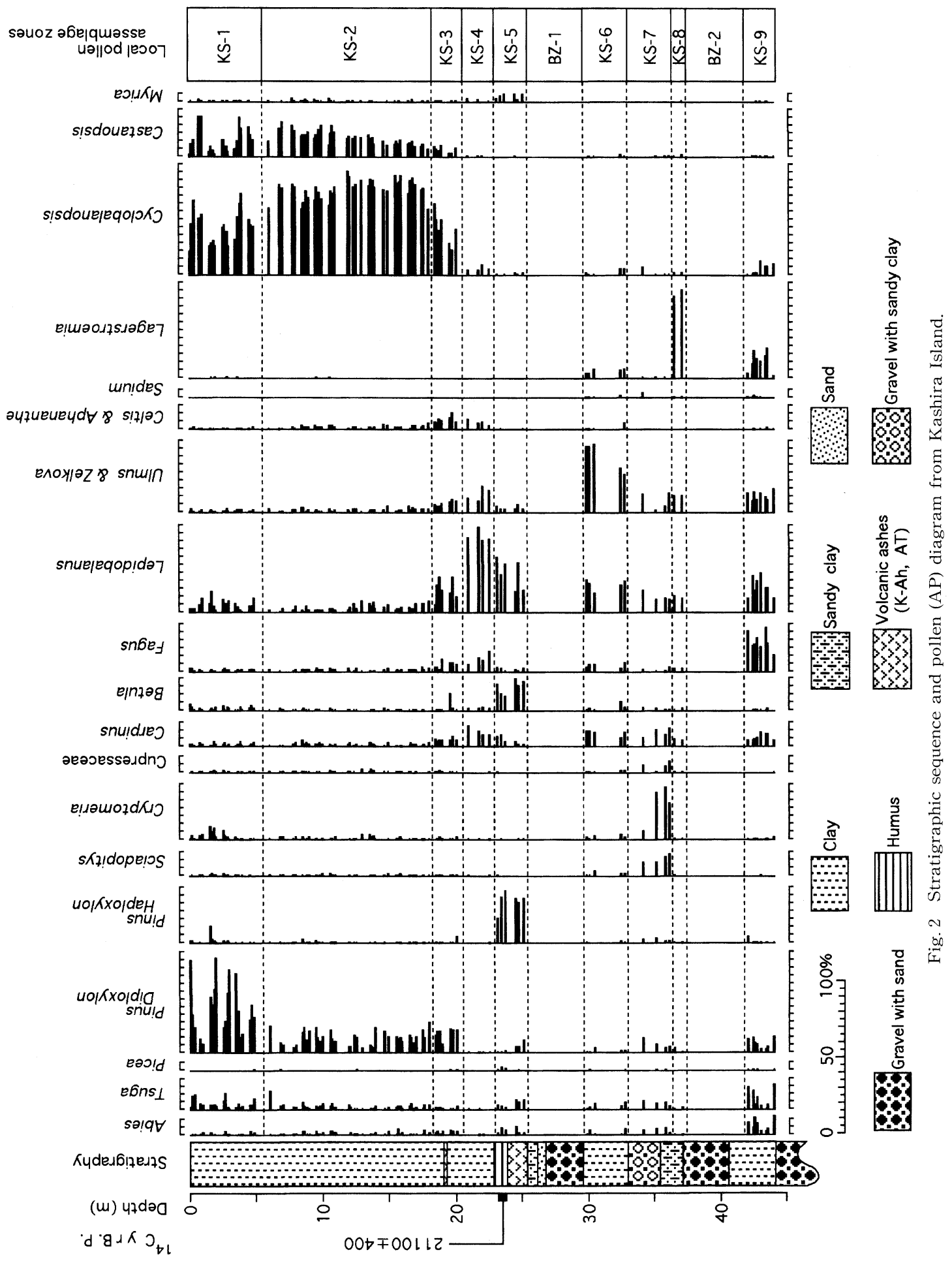




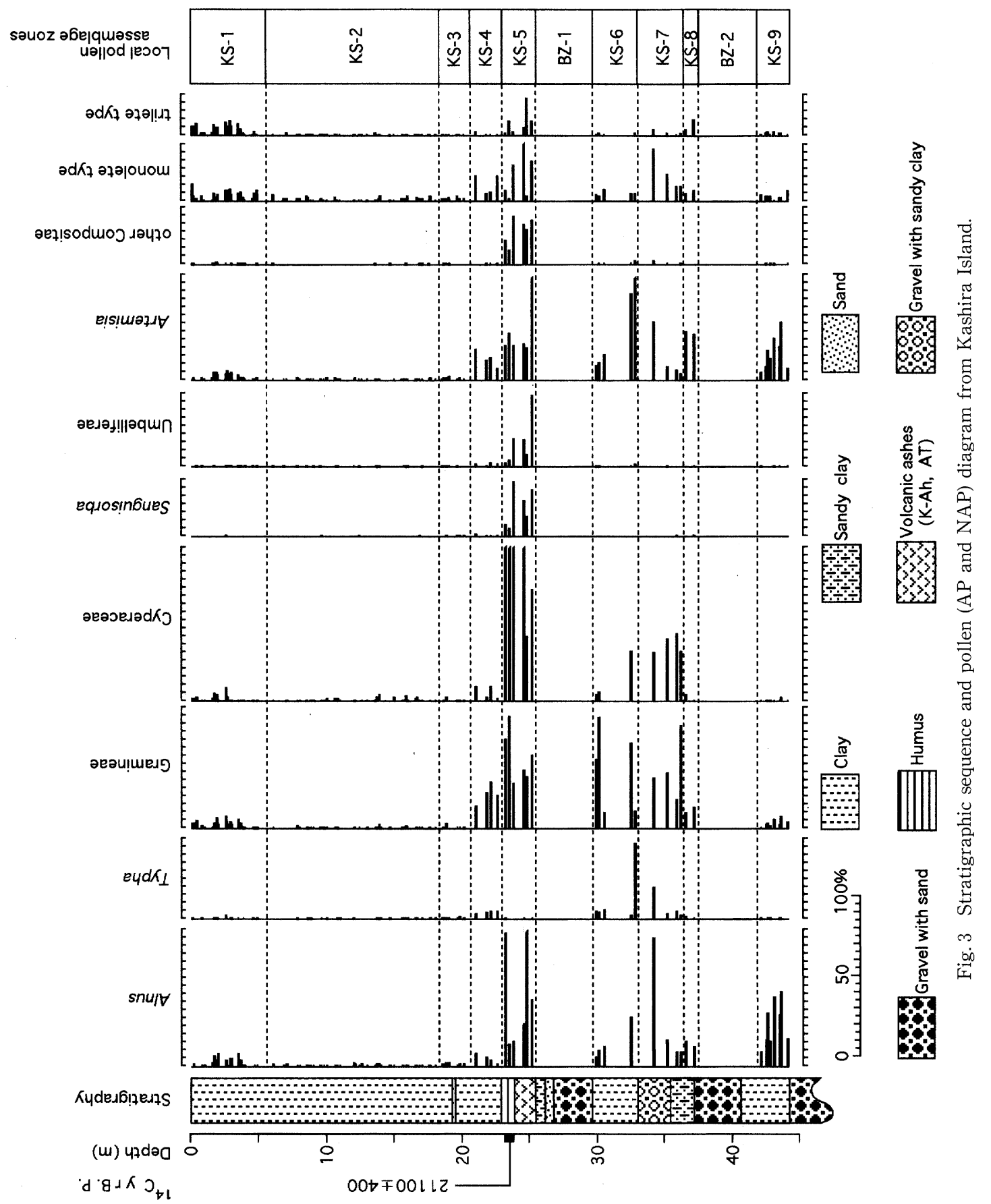


Cyclobalanopsis, Lepidobalanus, Castanea, Castanopsis, Ulmus and/or Zelkova, Celtis and/or Aphananthe, Euptelea, Liquidamber, Sapium, Buxus, Ilex, Acer, Aesculus, Tilia, Elaeagnus, Lagerstroemia, Corunus, Clethra, Ericaceae, Symplocos, Styrax, Ligustrum, Fraxinus, Weigela

NAP: Typha, Gramineae, Cyperaceae, Eriocaulon, Liliaceae, Persicaria and other Polygonaceae, Chenopodiaceae, Caryophyllaceae, Thalictrum and other Ranunculaceae, Sanguisorba, Geranium, Impatiens, Viola, Haloragis, Umbelliferae, Menyanthes and other Gentianaceae, Lonicera, Labiatae, Scabiosa, Artemisia and other Compositae.

FS: monolete type, trilete type, Lycopodiaceae, Osmundaceae.

The pollen analytical data are plotted in Fig. 2, except for Alnus, shrubs, herbs and ferns. The appearance tendencies of the main pollen types are shown below. The pollen of the temperate conifers, such as Abies and Tsuga, were dominant at the depth of 4,400-4,200 cm. Pinus (Diploxylon) pollen increased to $5-60 \%$ at the depth of $0-550$ $\mathrm{cm}$ but accounted for less than $30 \%$ at other depths. The pollen of the subarctic conifers, such as Pinus (Haploxylon), increased at the depth of $2,300-550 \mathrm{~cm}$ and rarely appeared at other depths. The pollen of the temperate conifers, such as Cryptomeria, Sciadopitys and Cupressaceae, showed a marked increase at the depth of $3,650-3,350 \mathrm{~cm}$ while being minimal at other depths. Carpinus pollen accounted for 5-15\% below $1,860 \mathrm{~cm}$ but showed a very low percentage. Betula pollen increased markedly at the depth of 2,550-2,300 $\mathrm{cm}$ but was low at other depths. The pollen of the cool temperate deciduous broad- leaved tree, such as Fagus, increased to 10-30\% at the depth of 4,400-4,200 $\mathrm{cm}$ while being less than $15 \%$ at other depths. Lepidobalnus pollen was dominant, at 10-15\%, at depth lower than 1,860 $\mathrm{cm}$ but was less than $15 \%$ above $1,860 \mathrm{~cm}$. Ulmus and/or Zelkova pollen are dominanted, at $5-45 \%$, below the depth of $1,860 \mathrm{~cm}$ but then diminished to very low percentages. Celtis and/ or Aphananthe pollen were slightly increased at the depth of 2,300-1,860 cm, were low above 1,860 $\mathrm{cm}$, and minimal below $2,990 \mathrm{~cm}$. The pollen of the warm temperate deciduous broad-leaved trees, such as Lagerstroemia and Sapium, were detected only at the depth lower than $2,990 \mathrm{~cm}$. This was especially true of Lagerstroemia pollen, which was detected at very high percentages. In contrast, the pollen of the warm temperate evergreen broad-leaved trees, such as Cyclobalanopsis and Castanopsis, were associated with very high percentages at the depth above $2,170 \mathrm{~cm}$.

Alnus pollen was characteristically found at the depth below $2,300 \mathrm{~cm}$. Among the herbs, Typha pollen was increased at 3,300-3,400 cm but was minimal at other depths. Gramineae pollen was dominant at the depths of 3,750-2,170 cm but accounted for less than $10 \%$ at other depths. Cyperaceae pollen was dominant at the depth of $3,650-2,300 \mathrm{~cm}$ but comprised less than $10 \%$ at other depths. Sanguisorba, Umbelliferae and other Compositae pollen showed a marked increase at the depth of 2,550-2,300 $\mathrm{cm}$ but were negligible at other depths. Artemisia pollen was dominant below $2,170 \mathrm{~cm}$ but at a very low percentage. The monolete spore type was dominant at the depths of $3,650-3,350 \mathrm{~cm}$ and 2,550-2,170 cm but constituted less than $10 \%$ at other depths. 
The trilete spore type was increased at the depths of $2,550-2,300 \mathrm{~cm}$ and $550-0 \mathrm{~cm}$.

\section{Palynological zonation}

1) Zone KS-9

Zone KS-9 was characterized by dominance of the pollen of the warm-temperate elements, such as Lagerstroemia and Cyclobalanopsis. Among the deciduous broad-leaved elements, Fagus, Lepidobalanus, Ulmus and/or Zelkova and Carpinus pollen were detected at high percentages. Among the coniferous elements, percentages of pollen were high (5-20\%) for Abies, Tsuga and Pinus (Diploxylon). About the other pollen, percentages for Alnus and Artemisia pollen were high.

\section{2) Barren zone-2}

No fossil pollen grains were found in barren zone-2, presumably because the sediments are derived mainly from sand and gravel. The separation of zones KS-9 and barren zone-2 reflected the appearance and disappearance of fossil pollen grains characteristic of zone KS-9.

\section{3) Zone $\mathrm{KS}-8$}

This zone is composed of only two samples. The warm-temperate element of Lagerstroemia pollen reached a high percentage, while that for Cyclobalanopsis pollen was low. The pollen of the deciduous broad-leaved elements, such as Fagus, Lepidobalanus and Ulmus and/or Zelkova, had percentages of 3 to $10 \%$. Some increments in Artemisia and Alnus pollen were also recognizable about the other pollen. The zonal line $(3,750$ $\mathrm{cm}$ ) between barren zone- 2 and 8 was demarcated by the sudden appearance of fossil pollen grains in zone KS-8.

\section{4) Zone KS-7}

This zone was characterized by dominance of the pollen of the temperate coniferous elements, such as Sciadopitys and Cryptomeria. Among the broadleaved elements, percentages for Carpinus, Lepidobalanus and Ulmus and/or Zelkova pollen were high. Alnus, Typha, Gramineae, Cyperaceae, Artemisia pollen and the monolete spore type were dominant about the other pollen. The division of zones KS- 8 and 7 was determined by increased Sciadopitys and Cryptomeria pollen and decreased Lagerstroemia pollen.

\section{5) Zone KS-6}

Zone KS-6 was characterized by the pollen of the warm-temperate elements, such as Lagerstroemia and Cyclobalanopsis, though the percentages of these pollen grains were low. Among the deciduous broad-leaved elements, percentages for Lepidobalanus, Ulmus and/or Zelkova and Carpinus pollen were high. The separation between KS-7 and 6 was based on decreased Sciadopitys and Cryptomeria pollen and increased Lepidobalanus pollen in zone $\mathrm{KS}-6$.

6) Barren zone-1

There were no pollen grains in this zone, like barren zone-2. The separation of zone KS-6 and barren zone- 1 was determined by the appearance and disappearance of the aforementioned pollen in zone $\mathrm{KS}-6$.

\section{7) Zone $\mathrm{KS}-5$}

This zone was characterized by dominance of the pollen of the subarctic elements, such as Pinus (Haploxylon) and Betula, and the cool-temperate elements, such as Lepidobalanus. Alnus, Gramineae, Cyperaceae, Sanguisorba, Umbelliferae, Artemisia and other Compositae pollen and 
monolete and trilete spore types were dominant about the other pollen. The separation of zones KS-6 and 5 was based on the sudden appearance of Pinus (Haploxylon), Betula and Lepidobalanus pollen in zone $\mathrm{KS}-5$.

\section{8) Zone $\mathrm{KS}-4$}

The pollen of the cool-temperate elements, such as Lepidobalanus, peaked in zone KS-4. The pollen of other deciduous broad-leaved elements, such as Fagus and Ulmus and/or Zelkova, were also abundant. The NAP is dominated by Gramineae, Artemisia pollen and the monolete spore type. The separation of zones KS-5 and 4 was determined by decreased Pinus (Haploxylon) and Betula pollen and increased the deciduous broad-leaved elements.

9) Zone KS-3

The pollen of the cool-temperate elements, such as Lepidobalanus, Fagus, Ulmus and/or Zelkova and Carpinus, and of the warm-temperate elements, such as Cyclobalanopsis and Castanopsis, were dominant in this zone. The NAP showed the lowest percentage. The separation of zones KS -4 and 3 was based on increased Pinus (Diploxylon) pollen and the evergreen broad-leaved elements.

10) Zone KS-2

The pollen of the warm-temperate elements, such as Cyclobalanopsis and Castanopsis, peaked this zone. The NAP showed the lowest percentage. The separation of zones KS-3 and 2 was based on decreased the deciduous broad-leaved elements and markedly increased the evergreen broad-leaved elements.

11) Zone KS-1

Percentage for Pinus (Diploxylon) pollen showed a sudden increase. Cyclobalanopsis and Castanopsis pollen were also dominant. The pollen of NAP, such as Gramineae, Cyperaceae, Artemisia and spores of Pteridophyta, were slightly increased. The separation of zones KS-2 and 1 was determined by a sudden increase in Pinus (Diploxylon) pollen.

\section{Discussion}

\section{The pollen zones}

We found the core to be divisible into nine pollen and two barren zones. In Osaka Bay, ca. $100 \mathrm{~km}$ to the east of Kashira Island (Furutani, 1989), Lake Mikata, ca. $170 \mathrm{~km}$ to the east-northeast of Kashira Island (Morita, 1994) and Lake Biwa, ca. $180 \mathrm{~km}$ to the northeast of Kashira Island (Miyoshi, 1994b), Lagerstroemia pollen is detected in the warm periods. Similar are obtained in the present study. Zones KS-9, 8 and 6 represent the warm periods, zone KS-4, 3, 2 and 1 the post glacial period, zone $\mathrm{KS}-8$ and 5 and barren zones- 1 and 2 the cold periods. In this core, the sediments of four warm and three cold periods are detected.

Zone KS-9 is the warm period, since Lagerstroemia pollen of the warm-temperate elements appears. Furthermore, Tsuji (1980), Miyoshi et al. (1991) and Morita (1994) reported that Lagerstroemia pollen appeared with Fagus pollen in the warm period. As we obtained similar results, this zone can be regarded as representing the warm period.

In barren zone-2 and 1, the fossil pollen can not be recognized. These zone consist mainly of sand and gravel, most probably relating to the regression during the cold period (Itano et al., 
1994). Such continental sediments sometimes have no fossil pollen grains (Itano et al., 1994; Yamanaka, 1984). Therefore, barren zone-2 and 1 are the cold period.

In zone KS-8, Lagerstroemia pollen of the warm-temperate element markedly increases, whereas the percentage of Cyclobalanopsis pollen is low. This zone is the warm period.

In zone KS-7, Lagerstroemia pollen of the warm-temperate element is absent, Cryptomeria and Cupressaceae pollen are abundant. This zone and be regarded as the cold period.

Zone KS-6 is characterized by the pollen of the warm-temperate elements, such as Lagerstroemia and Cyclobalanopsis. However, the percentages of these types of pollen are low and those of the deciduous broad-leaved elements are dominant. This zone is regarded as the warm period.

In zone $\mathrm{KS}-5$, the cool-temperate elements, such as Pinus (Haploxylon), Betula and Lepidobalanus, are dominant. From ${ }^{14} \mathrm{C}$-dating and tephra, this period is presumed to be the last full glacial period. Peat and humus accumulate above Aira volcanic ash in the Inland Sea. The pollen of wet land plants, such as Alnus, Gramineae and Cyperaceae, are abundant in this layer. Therefore, in the region of the Inland Sea, wet land may have existed at the end of the full glacial period. Subsequently, the clay accumulated because of transgression during the post glacial period. In this zone, there are few Myrica pollen grains, probably representing $M$. gale growing on the wet land in Hokkaido and the northern part of Honshu.

Zone KS- 4 is observed to be a transitional stage from the subarctic to the cool-temperate forests.
Deciduous broad-leaved elements, such as Lepidobalanus, are dominant in this zone. This period is the early stage of the post glacial period, pollen zone $\mathrm{R}$ - I in the Japanese pollen zone system (Tsukada, 1963). Lepidobalanus pollen from this zone was observed using SEM and was identified using the pollen key for Lepidobalanus by Fujiki et al. (1996). Most of the Lepidobalanus pollen grains were of the Quercus dentata type (Photo 1).

Zone $\mathrm{KS}-3$ is characterized by a sudden increase in the warm-temperate elements. From tephra, this period is assumed to be the early stage of the Jomon transgression and to correspond with the lower part of pollen zone R-II.

In zone KS-2, the warm-temperate elements, such as Cyclobalanopsis and Castanopsis, show a marked dominance. This period is assumed to represent the later stage of the Jomon transgression and to correspond with the upper part of pollen zone R-II. Cyclobalanopsis pollen from this zone was observed using SEM and was identified using the pollen key for Cyclobalanopsis by Fujiki and Miyoshi (1995). Most of the Cyclobalanopsis pollen grains were of the Quercus glauca type (Photo 1).

In zone KS-1, secondary forest elements, such as Pinus (Diploxylon) (ex. P. densiflora), increase rapidly. Hence this zone is recognized as a period in which the human impact on natural vegetation became evident.

From the pollen composition, four warm and three cold pollen zones were divided. These meanings of Quaternary chronicle become the subject of study for the future. 

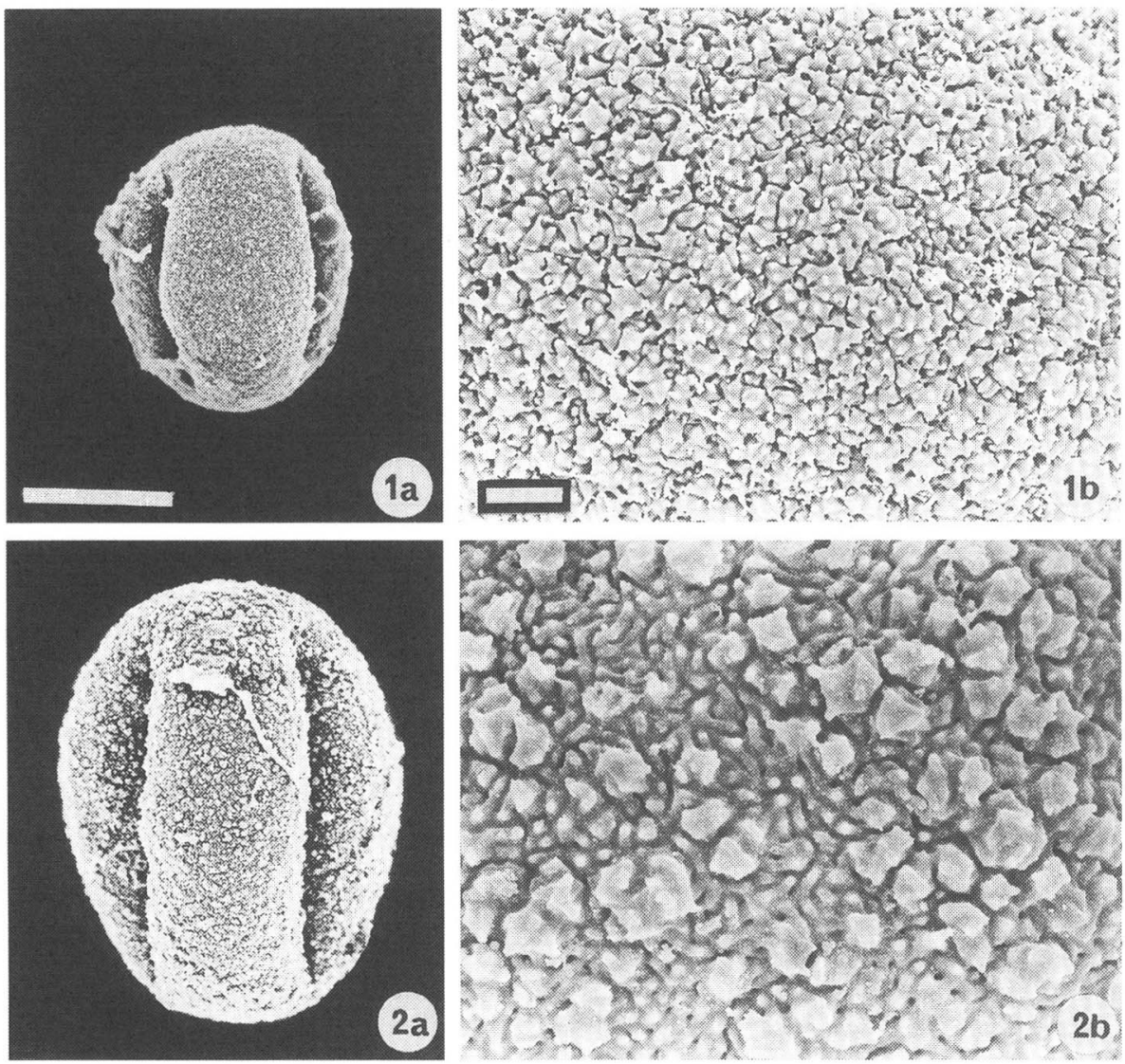

Photo 1 Fossil pollen of species from the subgenus Cyclobalanopsis and Lepidobalanus.

General view $\times 2,000$ (white line corresponds to $10 \mu \mathrm{m}$ ). Surface detail $\times 10,000$ (white line corresponds to $1 \mu \mathrm{m}$ ).

la-b Q. glauca type fossil pollen

2a-b Q. dentata type fossil pollen

2. Significant Lagerstroemia in the warm periods

Lagerstroemia pollen has been demonstrated during the warm periods (Tsuji, 1980; Furutani, 1989 ; Morita, 1994 ; Miyoshi, 1994b). At present, in Japan, Lagerstroemia (L. subcostata and $L$. subcostata var. fauriei) is distributed only in Yakushima Island, Tanegashima Island and Okinawa (Horikawa, 1972). In zone KS-9 of the warm period, the pollen of warm-temperate taxa, such as Lagerstroemia and Cyclobalanopsis, are detect- ed. The paleoclimate of zone KS-9 was warmer than the present climate because pollen of Lagerstroemia, which does not grow naturally around Kashira Island, was found. However, the pollen of Pinaceae and cool-temperate elements, such as Lepidobalanus, Fagus, Ulmus and/or Zelkova and Carpinus, are detected with those of the warmtemperate elements.

The warm-temperate elements are able to survive in winter and the cool-temperate elements are able to survive in summer. Hence the paleo- 
climate may have been relatively cool in the summer and warm in the winter, and thus different from the present climate.

\section{Conclusions}

The 44-m core from Kashira Island used for pollen analysis showed nine pollen and two barren zones. Layers with Lagerstroemia pollen were regarded as the sediments of the warm periods. Four warm and three cold pollen zones were divided. These meanings of Quaternary chronicle become the subject of study for the future.

Lagerstroemia pollen was found with those of the cool-temperate elements, such Lepidobalanus, Carpinus, Ulmus and/or Zelkova and Pinaceae. Hence, the paleoclimate may have been relatively cool in the summer and warm in the winter, and thus different from the present climate.

\section{Acknowledgment}

The authors would like to thank Mr. G. Tanaka, Fukken Research and Planning Corporation, for providing the valuable core. The authors also wish to thank Dr. S. Suzuki of Okayama University for guidance in the identification of volcanic ash.

(Accepted, July 10, 1998)

\section{References}

Fujiki, T. and Miyoshi, N. (1995): Pollen Morphology of Subgenus Cyclobalanopsis (Quercus, Fagaceae). Jpn. J. Palynol., 41, 21-29.

Fujiki, T., Morita Y. and Miyoshi N. (1996): Pollen Morphology of Subgenus Lepidobalanus (Quercus, Fagaceae) in Japan. Jpn. J. Palynol., 42, 107-116.

Furutani, M. (1989) : Stratigraphical Subdivision and Pollen Zonation of the Middle and Upper Pleistocene in the Coastal Area of Osaka Bay, Japan. J. of Geosci., Osaka city Univercity, 32, 91-121.
Hada, Y. (1975): The Hometown Nature Environment Investigation Report. Okayama Prefecture.

Hada, Y. (1996): The Nature Protection Basis Investigation Report. Okayama Prefecture.

Horikawa, Y. (1972): Atlas of the Japanese Flora. Gakken.

Itano, H., et al. (1994) : Pollen Analytical Studies of Coast Sediment in the Inland Sea. 3. Naruto City. Abstract of the Papers Presented at the 37th Annual Meeting of the Palynological Society of Japan. $18 \mathrm{p}$.

Machida, H and Arai, F. (1992): Atlas of Tephra in and around Japan. Tokyo Univ. Publication. $276 \mathrm{p}$.

Miyoshi, N and Yano, N. (1986): Late Pleistocene and Holocene Vegetatinal History of the Ohnuma Moor in the Chugoku Mountains, Western Japan. Rev. of Palaeobot. and Palynol. 46, 355-376.

Miyoshi, N., Horie, S. and Takemura, K. (1991) : Polenanalytische Untersuchungen an einem 85-Meter-Bohrkern aus dem Tokusa-Becken, Präfektur Yamaguchi, West-Japan. Horie S. ed : Die Geschichte des Biwa-Sees in Japan. Universitätsverlag Wagner, Innsbruck. 243-256.

Miyoshi, N. (1994a) : Pollen Analytical Study about the Vegetational Change and Climate Change on the Low Land of the Coast of the Inland Sea. The Study Report by the Ryobi Entei commemoration Foundation Research Grant. 43-51.

Miyoshi, N. (1994b): Vegetation and Climate from Pollen Analysis of Lake Biwa. Kagaku Asahi 11, 24-26.

Morita, Y. (1994): The Study Result Report. The Civilization and the Environment, 12, 2328.

Nakamura, J. (1959) : Pollen Analytical Study of Hachiman Moor. Sandan Gorge and Hachiman Heights. 153-160.

Ohwi, J. and Kitagawa, M. (1992): New Flora of Japan. 1,716 p. Shibundo Tokyo.

Tsuji, S. (1980) : Plant Fossil Assemblages from 
the Pleistocene Kissawa Formation in Oiso Hills, Central Japan (I). Quaternary Res., 19, 107-115.

Tsukada, M. (1963) : Umbrella Pine, Sciadopitys verticillata: Past and Present Distribution in Japan. Science, 142, 1680-1681.

Yamanaka, M. (1984): Palynological Study of the Deposits in Kochi City. Res. Rep. Kochi Univ., 22, 151-160.
Yamazaki, T. (1943): Die Pollenanalyse in den Torfmooren von Uranippon-besonders die Untersuchungen über die geschichtlichen Verwandlungen der Verbreitung von Cryptomeria japonica, I, Das Sugawara-Moor in der Pärfektur Tottori. Jap. For. Soc., 24, 65-80.

\section{瀬戸内海・頭島（岡山県日生町）周辺の花粉分析による}

\section{植生変遷史の研究}

\section{藤木 利之*・守田 益宗**・三好 教夫***}

岡山県日生町にある頭島で採取された $44 \mathrm{~m}$ ボーリングコアの花粉分析を行った。このコアは粘土・ 砂質粘土・砂・砂・腐植土・火山灰から成る。2,368-2,360 cm で 21,100土400 yr B.P. という ${ }^{14} \mathrm{C}$ 年代測 定結果が得られ，1,900-1,890 cm でアカホヤ火山灰，2,540-2,360 cm で姶良火山灰が確認されている。

分析の結果, 9 花粉帯と 2 無化石带が認められた。サルスベリ属の花粉が出現する層を温暖期, 化石 花粉の出現しない層は寒冷期と考えると,このコアは 4 回の温暖期 (KS-9, 8, 6, 4-1) と 3 回の寒冷期 (KS-7, 5, BZ-2, 1) に堆積したものである。KS-4〜1 は後水期である。

キーワード 花粉分析，寒・暖期サイクル，サルスベリ属

* 国際日本文化研究セン多- $=$ \% 610-1192 京都市西京区御陵大枝山町 3-2

** 岡山理科大学自然科学研究所自然植物園 干 700-0005 岡山市理大町 1-1

*** 岡山理科大学総合情報学部生物地球システム学科 テ 700-0005 岡山市理大町 1-1 